\title{
Gas Exchange Relations of Ungrafted Grapevines (cv. Carménère) Growing Under Irrigated Field Conditions
}

\author{
F. Jara-Rojas ${ }^{1}$, S. Ortega-Farías ${ }^{1,2^{*}}$, H. Valdés-Gómez ${ }^{1,2}$, C. Acevedo-Opazo ${ }^{1,2}$ \\ (1) Facultad de Ciencias Agrarias, Universidad de Talca, P.O. Box 747, Talca 346-0000, Chile \\ (2) CITRA, Universidad de Talca, P.O. Box 747, Talca 346-0000, Chile
}

Submitted for publication: July 2014

Accepted for publication: December 2014

Key words: Water stress, irrigation, stomatal sensitivity, Carménère grapevines

\begin{abstract}
A study was carried out to evaluate the leaf gas exchange relations and water-use efficiency (WUE) of ungrafted Carménère (Vitis vinifera L.) grapevines growing under field conditions and different levels of water stress. Stomatal conductance $\left(\mathrm{g}_{\mathrm{s}}\right)$, transpiration $(\mathrm{E})$, net $\mathrm{CO}_{2}$ assimilation $\left(\mathrm{A}_{\mathrm{N}}\right)$ and stem water potential ( $\Psi$ s) were measured at midday in a drip-irrigated commercial vineyard located in the Maule Valley (Chile) during three growing seasons (2005 to 2009). In addition, the instantaneous ( $\left.A_{N} / E\right)$ and intrinsic $\left(A_{N} / g_{s}\right)$ water-use efficiencies and stomatal sensitivity factor $(k)$ were estimated for the own-rooted grapevines. In this study a significant non-linear relationship was observed between $A_{\mathrm{N}}$ and $\mathbf{g}_{\mathrm{s}}\left(\mathrm{r}^{2}=\mathbf{0 . 8 2}\right)$, with values of $A_{\mathrm{N}}$ decreasing from 14.9 to $3.5 \mu \mathrm{mol} / \mathrm{m}^{2 /} \mathrm{sec}$ as $\mathrm{g}_{\mathrm{s}}$ diminished from 0.5 to $0.05 \mathrm{~mol} / \mathrm{m}^{2} / \mathrm{sec}$. This resulted in a progressive increase in WUEi (intrinsic water use efficiency). A significant linear relationship was observed between $\Psi s$ and $g_{s}\left(r^{2}=0.39\right)$ for measurements taken before and after véraison, with an increasing scattering from -1.6 to -0.4 MPa. Finally, $k$ decreased as water stress increased, with values of 234 and 120 for no and severe water stress respectively, while $k$ ranged from 264 to 480 and 255 to 297 for the measurements taken before and after véraison respectively. Based on the results obtained in the present study, the cultivar Carménère could be classified as drought tolerant at low water potentials, with a large range of physiological parameters changing in response to water stress.
\end{abstract}

\section{INTRODUCTION}

'Carménère' is an emblematic grapevine cultivar in Chile, and has recently been reintroduced to commercial production after its disappearance from Europe during the $19^{\text {th }}$ century. Because the Carménère grapevines are not spread worldwide, few studies on its leaf gas exchange relations and water-use efficiencies have been published. Furthermore, studies of cv. Carménère growing under field conditions and natural variability become an important topic, especially when taking into account the exceptional sanitary conditions in Chile (i.e. absence of Phylloxera), which allow grapevines to grow without grafting and to express their genotypic characteristics. Any knowledge about leaf gas exchange relations generated under field conditions could lead to the development of irrigation tools oriented to optimise water productivity and improve berry composition (Basile et al., 2012; Fernandes de Oliveira et al., 2013; Shellie, 2014).

Under semi-arid conditions, with no or a reduced water supply (i.e. regulated deficit irrigation), vine water stress gradually increases as both soil water depletion and atmospheric water demand are augmented during the growing season. In this case, photosynthetic activity decreases due to stomatal and non-stomatal limitations (Moutinho-Pereira et al., 2004). This situation occurs very slowly until a certain level of water deficit, after which the photosynthetic activity decreases rapidly (Pellegrino et al., 2006). Stomatal closure in response to chemical signals synthesised in the dehydrating roots (including abscisic acid) is generally accepted to be the main factor for the depletion of photosynthesis $\left(\mathrm{A}_{\mathrm{N}}\right)$ and gas exchange under mild to moderate water stress (Chaves et al., 2010). When the drought period is lengthened, dehydration is more severe, or other environmental stresses are superimposed and a decline in mesophyll photosynthesis may occur because of a down-regulation process (Medrano et al., 2002). If this condition persists, irreversible reductions in dry matter accumulation and failure of grape maturation may occur. Flexas et al. (2002) have suggested that the stomatal conductance $\left(\mathrm{g}_{\mathrm{s}}\right)$ could be an integrative indicator of water stress intensity in relation to photosynthesis (via a coupled $A_{N}-g_{s}$ relationship), as well as serving to unify data from different experiments and allowing the examination of a continuous gradient of water stress. Also, the $A_{N}-g_{s}$ relationship could be an informative tool to demonstrate how other types of stress may influence photosynthesis and

*Corresponding author: E-mail address: sortega@utalca.cl [Tel.: +56 71 2200426]

Acknowledgements: This study was supported by the Chilean government through the projects FONDECYT (N $\left.{ }^{\circ} 1030314\right)$ and FONDEF (N D10I1157), by the Universidad de Talca through the research programme, "Adaptation of Agriculture to Climate Change (A2C2)", and through doctoral scholarship support for Francisco Jara-Rojas 
water-use efficiency (Naor \& Wample, 1995). Cifre et al. (2005) suggest that three phases of photosynthesis response can be identified along a water stress gradient using stomatal conductance as a physiological indicator. In this regard, $\mathrm{g}_{\mathrm{s}}$ values are from 0.7 to $0.15,0.15$ to 0.05 and $<0.05 \mathrm{~mol} \mathrm{H}_{2} \mathrm{O}$ / $\mathrm{m}^{2} / \mathrm{sec}$ for the mild, moderate and severe water stress phases, respectively.

Since the water scarcity in viticultural areas is increasing progressively, the need for better water-use efficiency in grapevines is increasingly urgent. Moreover, additional knowledge of the mechanisms involved in grapevine tolerance to water stress and a better understanding of its genetic variability will be relevant to future breeding improvement (Chaves et al., 2010; Flexas et al., 2010). In this sense, water-use efficiency to leaf level has been studied in several grapevine cultivars around the world under very different growing conditions. Under different soil water and atmospheric conditions, stomatal regulation allows plants to reduce fluctuations in the water status of tissues and hold xylem integrity (Prieto et al., 2010). According to their stomatal control, vines can be classified physiologically into two categories (Tardieu \& Simonneau, 1998; Schultz, 2003; Prieto et al., 2010): (i) isohydric or near-isohydric vines that maintain tight stomatal regulation of the transpiration rate, resulting in nearly constant leaf water potential in drought-exposed and well-irrigated conditions. In contrast, (ii) anisohydric vines display lower stomatal control of transpiration, resulting in large fluctuations in leaf water potential under soil water deficit and high evaporative demand. These conditions allow the vines higher rates of gas exchange and assimilation.

Also, stomatal sensitivity and the degree of coupling of stomatal conductance and photosynthesis generally have been considered in relation to single variables, mostly because interactions between factors have been difficult to quantify in a simple way. In this regard, Ball et al. (1987) demonstrated that $g_{s}$ as a function of the 'Ball factor' (see Equation 4) would yield a linear relationship between $g_{s}$ and $\mathrm{A}_{\mathrm{N}}$ measured under different levels of $\mathrm{CO}_{2}$ concentration, light intensities, vapour pressure deficit and temperature. The slope of this relationship is named the sensitivity factor $(k)$, and it has been used successfully to evaluate stomatal responsiveness to water stress in several Vitis species and cultivars (Schultz et al., 1999; Schultz, 2000).

Unpublished field data suggest the Carménère cultivar presents an anisohydric-like behaviour, since stomatal conductance remains relatively high with moderate to strong water stress and saturating light conditions. As working hypothesis, the cv. Carménère has the ability to maintain a significant assimilation rate and stomatal conductance under increasing water stress. Thus, the objective of this study was to assess leaf gas exchange relations and water-use efficiency of ungrafted Carménère grapevines (Vitis vinifera L.) growing in a drip-irrigated commercial vineyard.

\section{MATERIALS AND METHODS}

\section{Field characterisation}

Field data were collected from a drip-irrigated Carménère commercial vineyard in the 2005/2006, 2007/2008 and $2008 / 2009$ growing seasons. The vineyard, with 11-year- old plants at the beginning of the experiment, was located in the Talca Valley, Maule Region, Chile (35'25.170' S, $71^{\circ} 33.228^{\prime} \mathrm{W}$, WGS 84; 137 m.a.s.1.). The own-rooted vines were trained on a Geneva double curtain (GDC) (spacing 3.3 $\mathrm{m}$ between rows and $1.5 \mathrm{~m}$ within the row) and pruned into two bilateral spur cordons (12 buds per cordon), with the fruiting zone at $1.8 \mathrm{~m}$ above ground and vine rows oriented $330^{\circ} \mathrm{NW}$. The canopy geometry of this training system was conserved after bloom (about mid-November) by hedging two or three times during the summer. The soil texture was clay loam with a rooting depth of $150 \mathrm{~cm}$. It is classified as Talca series (fine family, mixed, thermic Ultic Haploxeralf). From 0 to $150 \mathrm{~cm}$, the bulk density, field capacity, wilting point and available water were $1.36 \mathrm{~g} / \mathrm{cm}^{3}, 0.31 \mathrm{~m}^{3} / \mathrm{m}^{3}, 0.13$ $\mathrm{m}^{3} / \mathrm{m}^{3}$ and $0.18 \mathrm{~m}^{3} / \mathrm{m}^{3}$, respectively. Standard agronomical practices were performed during each season for sanitary care and productivity.

\section{Water requirements and irrigation}

Vineyard evapotranspiration was calculated as:

$\mathrm{ET}_{v}=\mathrm{Kc} \times \mathrm{ET}_{0}$

where $\mathrm{ET}_{v}$ is the actual evapotranspiration of the vineyard $(\mathrm{mm} /$ day $), \mathrm{ET}_{0}$ is the reference evapotranspiration $(\mathrm{mm} /$ day) computed using the Penman-Monteith model (Allen et al., 1998), and Kc is the crop coefficient assigned according to phenological stage (dimensionless). Kc values were 0.11, $0.24,0.61$ and 0.49 for budburst, setting, véraison and near to harvest respectively. These Kc values were obtained using measurements of midday stem water potential ( $\Psi$ s) and soil water content during a three-year experiment (unpublished data), and were similar to those indicated by Acevedo-Opazo et al. (2010) and Ortega-Farias et al. (2005).

Water was supplied to the vineyard making use of two 2.0 $\mathrm{L} / \mathrm{h}$ drippers per plant at a frequency of two times per week. Also, the irrigation timing varied according to atmospheric demand and the application of regulated deficit irrigation with the aim of improving berry quality. Due to the high soil water-holding capacity of the rooting zone $(270 \mathrm{~mm})$, the first irrigations were applied in late December or early January, which corresponded to the phenological stages between post-setting and before véraison. In this case, the farmer applied about 2 990, 2570 and $3140 \mathrm{~m}^{3} / \mathrm{ha} /$ season, while the yield was 9.0, 9.2 and 11.0 t/ha for the 2005/2006, $2007 / 2008$ and 2008/2009 growing seasons respectively. The increase in water application was associated with a higher atmospheric demand observed during the last season

\section{Climatic variables}

Standard weather variables used to calculate $\mathrm{ET}_{0}$ from a reference grass were collected at 30-min intervals using an automatic meteorological station (Adcon Telemetry, model A730, Klosterneuburg, Austria), located about $8 \mathrm{~km} \mathrm{NW}$ from the experimental site. Air temperature (T), relative humidity $(\mathrm{RH})$, solar radiation $\left(\mathrm{R}_{\mathrm{s}}\right)$, precipitation $(\mathrm{P})$, wind velocity $(\mathrm{Wv})$ and direction $(\mathrm{Wd})$ were measured from 1 May to 30 April of each year. 


\section{Growing degree-days and seasonal dryness characterisa- tion}

To characterise the climatic conditions at the experimental site, growing degree-days (GDD, ${ }^{\circ} \mathrm{Cd}$ ) and dryness index (DI, mm) were estimated for each growing season. The GDD were calculated as:

$\mathrm{GDD}=\sum_{i=1}^{n}\left[0.5 \times\left(\mathrm{T}_{\max }+\mathrm{T}_{\min }\right)-\mathrm{T}_{b}\right]$

where $\mathrm{T}_{\max }$ and $\mathrm{T}_{\min }$ are daily maximum and minimum temperatures $\left({ }^{\circ} \mathrm{C}\right)$ respectively, and $\mathrm{T}_{b}$ is the base temperature $\left(10^{\circ} \mathrm{C}\right)$. The phenological stages of the vines were observed in 18 representative vines across the experimental field using the modified Eichhorn and Lorenz system (Coombe, 1995). Two fruit-bearing shoots per plant were selected and labelled for the successive readings.

For the three seasons, the dryness index (DI, mm) was calculated following the methodology proposed by Tonietto and Carbonneau (2004):

$\mathrm{DI}=W_{0}+\sum_{01.10}^{31.03}\left(P-T_{v}-E_{s}\right)$

where $W_{0}$ is the initial useful soil water reserve available at the rooting depth $(200 \mathrm{~mm}), P$ is the monthly precipitation (mm), $T_{v}$ is the monthly potential transpiration in the vineyard (mm) and $E_{s}$ is the monthly direct evaporation from the soil (mm). Using DI, climates are considered to be humid (DI > $150 \mathrm{~mm})$, sub-humid $(150>\mathrm{DI}>50 \mathrm{~mm})$, moderately dry $(50>$ DI $>-100 \mathrm{~mm})$ or very dry $(\mathrm{DI}<-100 \mathrm{~mm})$.

\section{Leaf gas exchange measurements}

An infrared gas analyser (ADC BioScientific Ltd., model LCi, Hoddesdon, UK) was used to estimate midday values of photosynthetically active radiation (PAR), stomatal conductance $\left(\mathrm{g}_{\mathrm{s}}\right)$, transpiration $(\mathrm{E})$, net $\mathrm{CO}_{2}$ assimilation $\left(\mathrm{A}_{\mathrm{N}}\right)$ and $\mathrm{CO}_{2}$ concentrations both internal $(\mathrm{Ci})$ and external (Ca) to the atmosphere. $\mathrm{CO}_{2}$ mesophyll conductance $\left(\mathrm{g}_{\mathrm{m}}, \mathrm{A}_{\mathrm{N}} /\right.$ $\mathrm{Ci}$ ), intrinsic (WUEi, $\mathrm{A}_{\mathrm{N}} / \mathrm{g}_{\mathrm{S}}$ ) and instantaneous (WUE, $\mathrm{A}_{\mathrm{N}} / \mathrm{E}$ ) water-use efficiencies also were calculated. Mesophyll conductance to $\mathrm{CO}_{2}$ was calculated as the ratio of $\mathrm{A}_{\mathrm{N}} /(\mathrm{Ci}$ $\mathrm{Cc}$ ), assuming that the $\mathrm{CO}_{2}$ partial pressure at the site of carboxylation $(\mathrm{Cc})$ is zero (Candolfi-Vanconcelos \& Koblet, 1991; Moutinho-Pereira et al., 2004).

A total of 362 fully expanded, mature, sun-exposed, healthy leaves were chosen from the mid-zone of the canopy ( $6^{\text {th }}$ leaf from the tip on fruit-bearing shoots). The measurements of leaf gas exchange were made between 12:00 and 14:00 local time (solar zenith) on fully sunny days without changing the original position of the selected leaves in the canopy and maintaining the same light regime, ensuring a saturating sunlight exposure of the leaves (PAR > $\left.800 \mu \mathrm{mol} / \mathrm{m}^{2} / \mathrm{sec}\right)$.

\section{Plant water status}

To evaluate vine water status, midday stem water potential ( $\mathrm{s}_{\mathrm{s})}$ was measured using a pressure chamber (PMS Instrument Co., model 600, Corvallis, Oregon, USA). Fully expanded, healthy leaves were wrapped with plastic transparent film and aluminium foil at least $2 \mathrm{~h}$ before taking the measurements, allowing an equilibrium between leaf and plant xylem water status to be achieved (Scholander et al., 1965; Begg \& Turner, 1970; Choné et al., 2001). Care was taken to minimise water loss during the transfer of the leaf to the chamber, so less than $30 \mathrm{sec}$ were allowed to pass between the excision of the petiole and the measurement. The measurements of $\Psi$ s and leaf gas exchange were taken every 20 days from December (one month before véraison) to March (near harvest) in each growing season.

Several thresholds of plant water status to define water stress levels have been developed for different grapevine cultivars (Carbonneau \& Costanza, 2004; Sibille et al., 2007; Van Leeuwen et al., 2009). To define the level of water stress in this study, data were divided into ranges according to the thresholds proposed by Van Leeuwen et al. (2009): i) no water deficit $\left(\Psi_{\mathrm{s}}>-0.6 \mathrm{MPa}\right)$, ii) weak water deficit (-0.9 $\left.\mathrm{MPa}<\Psi_{\mathrm{s}}<-0.6 \mathrm{MPa}\right)$, iii) moderate to weak water deficit $\left(-1.1 \mathrm{MPa}<\Psi_{\mathrm{S}}<-0.9 \mathrm{MPa}\right)$, iv) moderate to severe water deficit $\left(-1.4 \mathrm{MPa}<\Psi_{\mathrm{s}}<-1.1 \mathrm{MPa}\right)$ and $\left.\mathrm{v}\right)$ severe water deficit (-1.4 MPa $\left.>\Psi_{\mathrm{s}}\right)$.

\section{Stomatal sensitivity factor}

Cultivar-specific stomatal sensitivity was analysed using the model approach of Ball et al. (1987) that allows the evaluation of the stomatal conductance response to the combined effects of climatic variables through a stomatal sensitivity factor $(k)$ calculated by a linear regression analysis (Prieto et al., 2010):

$\mathrm{g}_{s}=\mathrm{g}_{0}+k \times \mathrm{A}_{\mathrm{N}}(\mathrm{RH} / \mathrm{Ca})$

where $\mathrm{g}_{0}$ is a residual stomatal conductance $\left(\mathrm{mmol} / \mathrm{m}^{2} /\right.$ sec); $\mathrm{A}_{\mathrm{N}}$ is the net $\mathrm{CO}_{2}$ assimilation $\left(\mu \mathrm{mol} / \mathrm{m}^{2} / \mathrm{sec}\right)$; $\mathrm{RH}$ is the relative humidity $(\%)$; and $\mathrm{Ca}$ is $\mathrm{CO}_{2}$ concentration at the leaf surface $(\mu \mathrm{mol} / \mathrm{mol})$. Also, the factor ' $A_{N}(\mathrm{RH} / \mathrm{Ca})$ ' is termed the 'Ball factor'. Schultz et al. (1999) indicated that a higher value of $k$ means less stomatal responsiveness to water stress (inverse relationship between $k$ and stomatal closure control), consequently leading to lower WUE and WUEi.

\section{Data filtering and analysis}

The whole database of gas exchange was submitted to an exploratory data analysis to determine the existence of measurement errors. Data were removed from the dataset when (i) the temperature within the infrared gas analyser chamber was over $42{ }^{\circ} \mathrm{C}$ (Jacobs et al., 1996; Jara-Rojas et al., 2009), and (ii) when $\mathrm{g}_{\mathrm{s}}$ and/or Ci where close or equal to zero under saturating sunlight conditions (PAR $>800 \mu \mathrm{mol} /$ $\mathrm{m}^{2} / \mathrm{sec}$; Prieto et al., 2010).

\section{Statistical analysis}

Non-linear regressions between $\mathrm{A}_{\mathrm{N}}$ and $\mathrm{g}_{\mathrm{s}} \mathrm{Ci}$ and $\mathrm{g}_{\mathrm{s}}, \mathrm{g}_{\mathrm{m}}$ and $g_{s}, A_{N} / g_{s}$ and $g_{s}$ and $A_{N} / E$ and $g_{s}$ were developed for different levels of vine water status. For these levels, linear regressions between $g_{s}$ and the 'Ball factor' also were done to calculate the values of $k$ before and after véraison. It is important to indicate that the stomatal sensitivity factor corresponds to the slope of the linear regression. The coefficient of determination $\left(\mathrm{r}^{2}\right)$ was used to evaluate how well the regression line represents the data (percentage of the data that is the closest to the line of best fit. 
Furthermore, a statistical analysis of climatic data was performed using the Kruskal-Wallis range test, while that for vine water status was done using a two-way ANOVA. The mean separation was done using Tukey's test at a 95\% confidence level (P-value $<0.05)$.

\section{RESULTS}

\section{Local growing conditions}

In general, the seasonal mean values of $\mathrm{T}_{\text {max }}, \mathrm{VPD}$ and GDD were statistically higher during the 2008/2009 season than during the other seasons (Table 1). Also, the seasonal $\mathrm{T}_{\min }$ was lower during the 2007/2008 season in comparison with the other seasons, but there was not a significant difference in $R_{\mathrm{s}}$ values among the seasons. The highest atmospheric demand was observed between setting and véraison, with the mean values of $\mathrm{T}_{\max }$ and $\mathrm{T}_{\min }$ ranging between 29.3 and $30.3^{\circ} \mathrm{C}$ and 12.5 and $13.1^{\circ} \mathrm{C}$, respectively. The mean seasonal values of VPD ranged between 0.6 and $0.9 \mathrm{kPa}$, while those of $\mathrm{R}_{\mathrm{s}}$ were between 21.4 and $22.6 \mathrm{MJ} / \mathrm{m}^{2} / \mathrm{d}$. The seasonal values of GDD were between 1632 and $1793^{\circ} \mathrm{C}$, which, according to Tonietto and Carbonneau (2004), indicates that there were good climatic conditions to reach appropriate berry maturation. Table 2 indicates that the cumulative values of $\mathrm{ET} v$ and $\mathrm{ET}_{0}$ ranged between 315 and $349 \mathrm{~mm}$ and

TABLE 1

Mean values of climatic variables for the main phenological stages of a drip-irrigated Carménère vineyard.

\begin{tabular}{|c|c|c|c|c|c|}
\hline & Leaf fall to budburst & Budburst to setting & Setting to véraison & Véraison to harvest & Season (Oct-Apr) \\
\hline \multicolumn{6}{|l|}{$\mathrm{T}_{\max }\left({ }^{\circ} \mathrm{C}\right)$} \\
\hline $2005 / 2006$ & $14.4 \mathrm{a}$ & $23.8 \mathrm{~b}$ & $29.3 \mathrm{~b}$ & 25.7 & $25.8 \mathrm{~b}$ \\
\hline $2007 / 2008$ & $12.9 \mathrm{~b}$ & $23.7 \mathrm{~b}$ & $29.9 \mathrm{a}$ & 26.2 & $26.1 \mathrm{~b}$ \\
\hline $2008 / 2009$ & $14.4 \mathrm{a}$ & $25.2 \mathrm{a}$ & $30.3 \mathrm{a}$ & 27.0 & $27.1 \mathrm{a}$ \\
\hline Significance & $*$ & $*$ & $*$ & ns & $*$ \\
\hline \multicolumn{6}{|l|}{$\mathrm{T}_{\min }\left({ }^{\circ} \mathrm{C}\right)$} \\
\hline $2005 / 2006$ & $5.8 \mathrm{a}$ & $9.6 \mathrm{a}$ & 13.1 & 9.8 & $10.5 \mathrm{a}$ \\
\hline $2007 / 2008$ & $2.2 \mathrm{c}$ & $8.5 \mathrm{~b}$ & 13.0 & 9.6 & $9.9 \mathrm{~b}$ \\
\hline $2008 / 2009$ & $4.8 \mathrm{~b}$ & $9.4 \mathrm{a}$ & 12.5 & 10.1 & $10.4 \mathrm{a}$ \\
\hline Significance & $*$ & $*$ & ns & ns & $*$ \\
\hline \multicolumn{6}{|l|}{ VPD (kPa) } \\
\hline $2005 / 2006$ & 0.2 & 0.5 & $0.9 \mathrm{~b}$ & $0.6 \mathrm{~b}$ & $0.6 \mathrm{c}$ \\
\hline $2007 / 2008$ & 0.2 & 0.7 & $1.2 \mathrm{a}$ & $0.7 \mathrm{~b}$ & $0.8 \mathrm{~b}$ \\
\hline $2008 / 2009$ & 0.2 & 0.7 & $1.3 \mathrm{a}$ & $0.9 \mathrm{a}$ & $0.9 \mathrm{a}$ \\
\hline Significance & ns & ns & $*$ & $*$ & $*$ \\
\hline \multicolumn{6}{|l|}{$\mathrm{R}_{\mathrm{s}}\left(\mathrm{MJ} \mathrm{m}^{2} / \mathrm{d}\right)$} \\
\hline $2005 / 2006$ & 8.5 & $22.1 \mathrm{~b}$ & 28.5 & 17.1 & 21.4 \\
\hline $2007 / 2008$ & 9.2 & $24.7 \mathrm{ab}$ & 27.4 & 18.4 & 22.6 \\
\hline $2008 / 2009$ & 8.4 & $23.2 \mathrm{a}$ & 26.9 & 18.6 & 22.1 \\
\hline Significance & ns & $*$ & ns & ns & ns \\
\hline \multicolumn{6}{|l|}{$\operatorname{GDD}\left({ }^{\circ} \mathrm{Cd}\right)$} \\
\hline $2005 / 2006$ & $135 \mathrm{a}$ & $483.5 \mathrm{ab}$ & 518.7 & 648 & $1650.5 \mathrm{~b}$ \\
\hline $2007 / 2008$ & $45 \mathrm{~b}$ & $438.5 \mathrm{~b}$ & 534.6 & 659 & $1631.9 \mathrm{~b}$ \\
\hline $2008 / 2009$ & $118 \mathrm{a}$ & $537.7 \mathrm{a}$ & 530.9 & 725 & $1793.2 \mathrm{a}$ \\
\hline Significance & $*$ & $*$ & ns & ns & $*$ \\
\hline
\end{tabular}

$\mathrm{T}_{\max }=$ maximum temperature; $\mathrm{T}_{\min }=$ minimum temperature; $\mathrm{VPD}=$ average leaf-to-air vapour pressure deficit; $\mathrm{R}_{\mathrm{s}}=$ average solar radiation; GDD $=$ growing degree-days.

* Columns with different letters denote statistical differences $(\mathrm{P}$-value $<0.05)$; ns $=$ non-significant differences.

TABLE 2

Cumulative values of precipitation $(\mathrm{P})$, actual $\left(\mathrm{ET}_{v}\right)$ and reference $\left(\mathrm{ET}_{0}\right)$ evapotranspiration and dryness index (DI) from October to March.

\begin{tabular}{lcccc}
\hline \multicolumn{1}{c}{ Seasons } & $\mathrm{P}(\mathrm{mm})$ & $\mathrm{ET}_{v}(\mathrm{~mm})$ & $\mathrm{ET}_{0}(\mathrm{~mm})$ & $\mathrm{DI}(\mathrm{mm})$ \\
\hline $2005 / 2006$ & 63 & 315 & 893 & -115 \\
$2007 / 2008$ & 77 & 332 & 945 & -130 \\
$2008 / 2009$ & 46 & 349 & 983 & -151 \\
\hline
\end{tabular}


between 893 and $983 \mathrm{~mm}$ respectively. Moreover, the DI was between -115 and $-151 \mathrm{~mm}$, indicating that the area was very dry. Under these atmospheric conditions, the mean values of $\Psi \mathrm{s}$ were maintained between -0.69 and $-1.05 \mathrm{MPa}$ from setting to veraison, indicating that the farmer maintained the Carménère commercial vineyard under a water status from moderate to weak water deficit (Fig. 1) (Van Leeuwen et al., 2009). It was only in the $2005 / 2006$ growing season

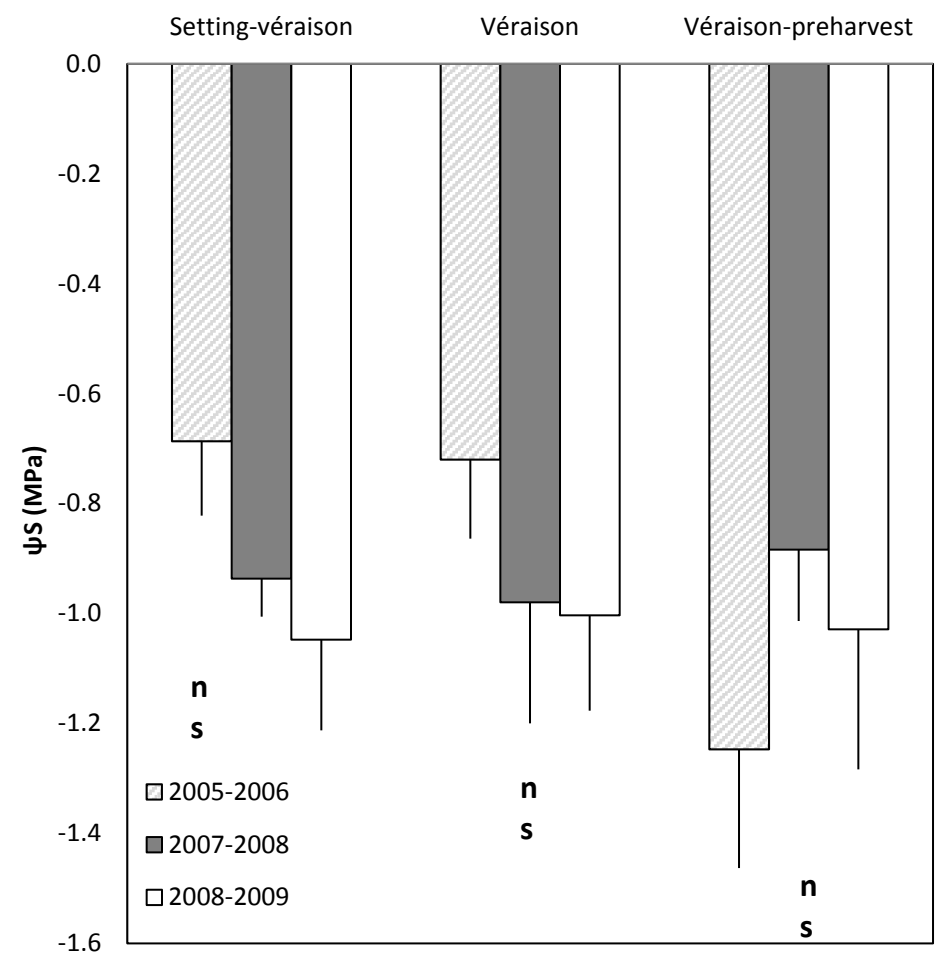

FIGURE 1

Mean values of midday stem water potential ( $\left.\Psi_{\mathrm{s}}\right)$ during setting-véraison, véraison and véraison-pre-harvest of a drip-irrigated Carménère vineyard. Each bar represents a line indicating the standard deviation ( $\mathrm{n}>24$ for each set). ns indicates that there were not significant differences between seasons or phenological stages.

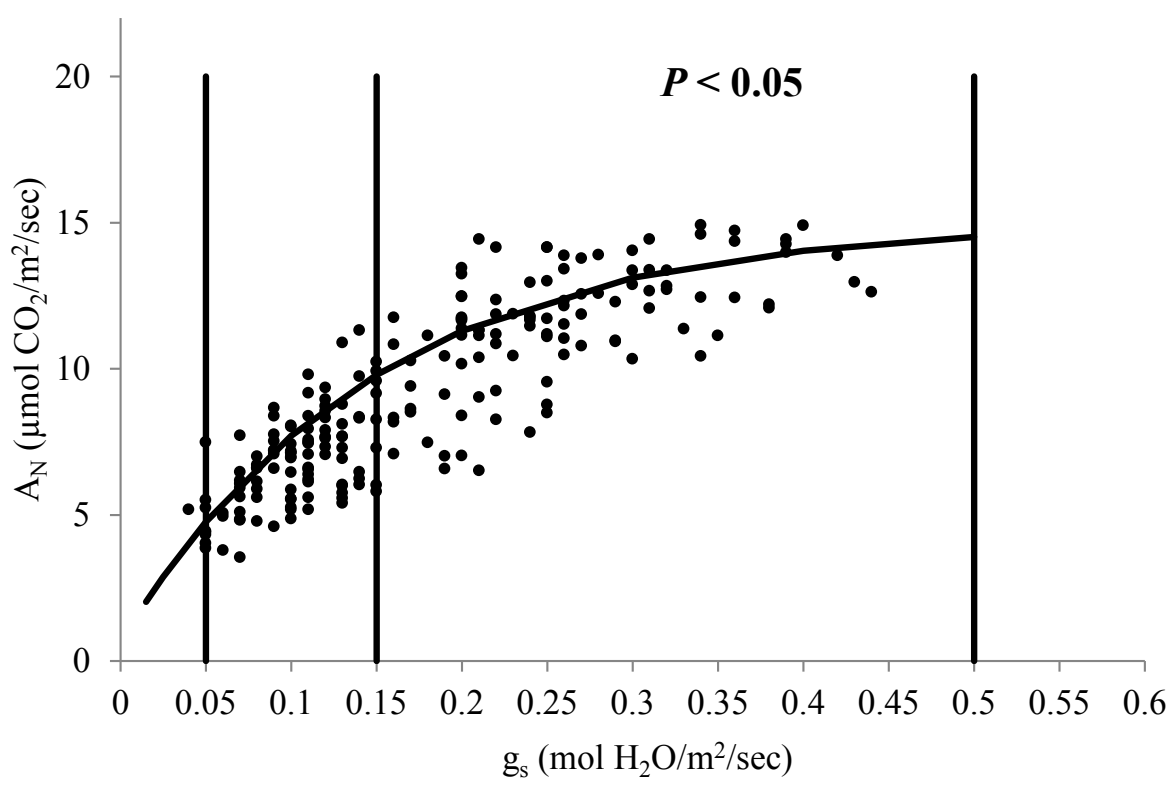

FIGURE 2

Relationships between net $\mathrm{CO}_{2}$ assimilation $\left(\mathrm{A}_{\mathrm{N}}\right)$ and stomatal conductance $\left(\mathrm{g}_{\mathrm{s}}\right)$ of grapevines (cv. Carménère) growing at field conditions. Solid vertical lines represent the threshold values proposed by Cifre et al. (2005) to define water stress using stomatal conductance as an index: $\mathrm{g}_{\mathrm{s}}$ values from 0.5 to $0.15,0.15$ to 0.05 and $<0.05 \mathrm{~mol} \mathrm{H}_{2} \mathrm{O} / \mathrm{m}^{2} / \mathrm{sec}$ correspond to mild, moderate and severe water stress phases, respectively. 
that the vineyard showed values of $\Psi_{\mathrm{s}}<-1.4$ (severe water stress) during post-véraison and pre-harvest; during the other seasons, the vineyard was always maintained under $\Psi_{\mathrm{s}}>-1.1 \mathrm{MPa}$. It is important to indicate that there were no significant differences in mean $\Psi$ s between seasons and phenological stages.

\section{Gas exchange performance}

For the field-grown grapevines, a significant non-linear regression was observed between $\mathrm{A}_{\mathrm{N}}$ and $\mathrm{g}_{\mathrm{s}}\left(\mathrm{r}^{2}=0.82\right)$, in spite of the large scattering observed in this study (Fig. 2). Also, the results show that the net $\mathrm{CO}_{2}$ assimilation was between
5.8 and 14.9 and 3.5 and $11.3 \mu \mathrm{mol} \mathrm{CO}_{2} / \mathrm{m}^{2} / \mathrm{sec}$ for Carménère vines under mild ( $g_{\mathrm{s}}$ values from 0.5 to $0.15 \mathrm{~mol} / \mathrm{m}^{2} / \mathrm{sec}$ ) and moderate $\left(\mathrm{g}_{\mathrm{s}}\right.$ values from 0.15 to $\left.0.05 \mathrm{~mol} / \mathrm{m}^{2} / \mathrm{sec}\right)$ water stress respectively. In Fig. 3A, a significant non-linear relationship between $\mathrm{Ci}$ and $\mathrm{g}_{\mathrm{s}}\left(\mathrm{r}^{2}=0.54\right)$ can be observed, with an important scattering of the $g_{s}$ value ranging from 0.05 to $0.15 \mathrm{~mol} / \mathrm{m}^{2} / \mathrm{sec}$. The mean values of Ci were $233.4( \pm 16.9)$ and $211.2( \pm 25) \mu \mathrm{mol} \mathrm{CO}_{2 /} \mathrm{mol}$ air for the mild and moderate water stress phases respectively. In Fig. 3B, a significant non-linear regression can be observed between the mesophyll conductance of the leaf $\left(g_{m}=A_{N} / C i\right)$ and $g_{s}\left(r^{2}=0.49\right)$, with a very large scattering of $g_{s}$, ranging between 0.15 and
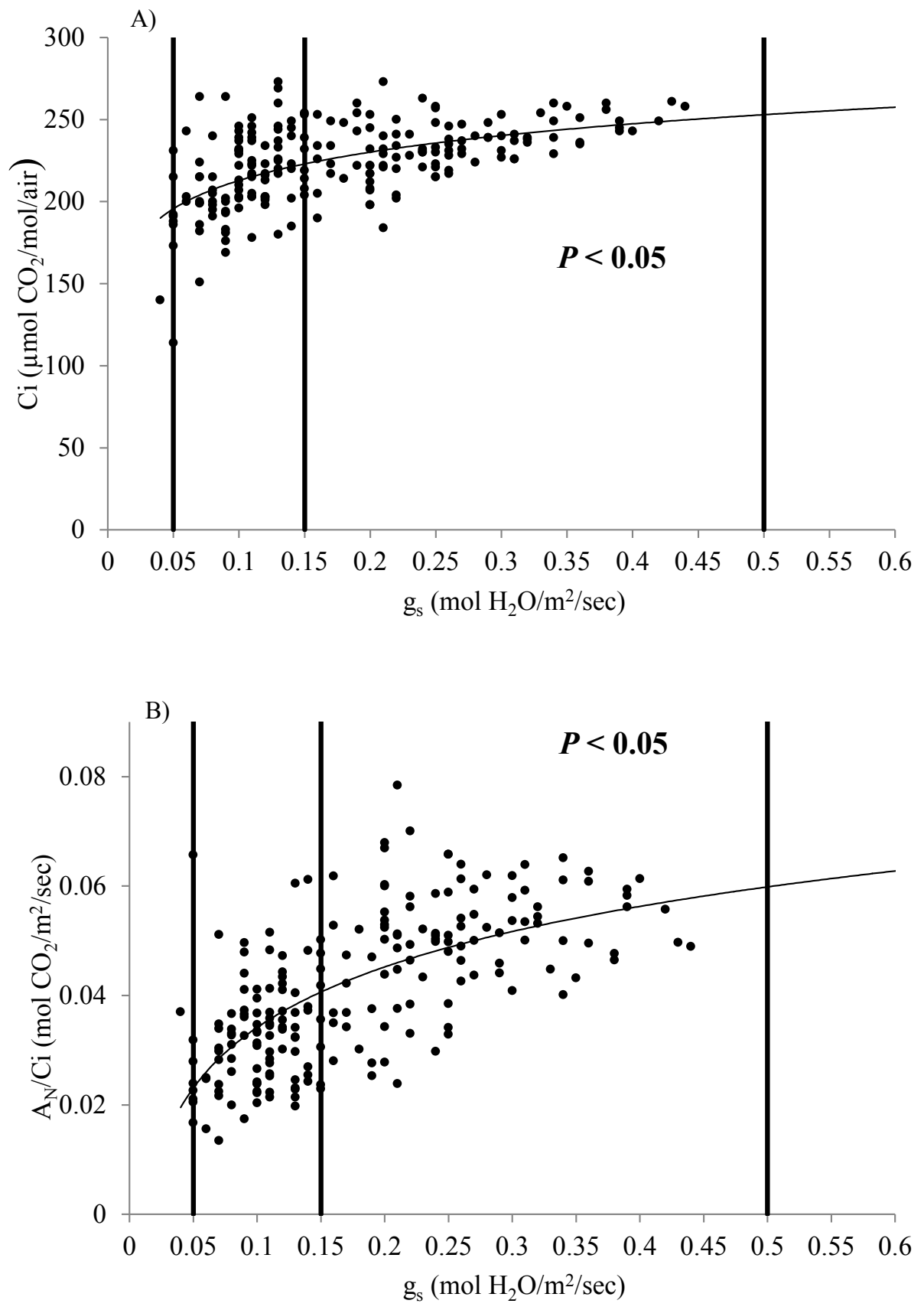

FIGURE 3

Relationships between internal $\mathrm{CO}_{2}$ concentration $(\mathrm{Ci})$ and $\mathrm{g}_{\mathrm{s}}$ and between $\mathrm{A}_{\mathrm{N}} / \mathrm{Ci}$ ratio and $\mathrm{g}_{\mathrm{s}}$ of grapevines (cv. Carménère) growing at field conditions. Solid vertical lines represent the threshold values proposed by Cifre et al. (2005) to define water stress using stomatal conductance as an index: $\mathrm{g}_{\mathrm{s}}$ values from 0.5 to $0.15,0.15$ to 0.05 and $<0.05 \mathrm{~mol} \mathrm{H}_{2} \mathrm{O} / \mathrm{m}^{2} / \mathrm{sec} \mathrm{correspond}$ to mild, moderate and severe water stress phases,respectively. 


\section{$0.5 \mathrm{~mol} / \mathrm{m}^{2} / \mathrm{sec}$.}

Figs $4 \mathrm{~A}$ and $4 \mathrm{~B}$ show the intrinsic $\left(\mathrm{WUEi}=\mathrm{A}_{\mathrm{N}} / \mathrm{g}_{\mathrm{s}}\right)$ and instantaneous (WUE $=A_{N} / E$ ) water-use efficiencies of the cv. Carménère for the different values of stomatal conductance. The values of WUEi and WUE increased from mild to moderate water stress, but the pattern of WUEi was better than that of WUE. The mean values of WUEi and WUE for mild water stress ( $\mathrm{g}$ s values from 0.5 to $0.15 \mathrm{~mol} /$ $\mathrm{m}^{2} / \mathrm{sec}$ ) ranged between 28.7 and $-73.4 \mu \mathrm{mol} / \mathrm{mol}$ and 0.8 to $2.9 \mathrm{mmol} / \mathrm{mol}$, respectively, while those for moderate water stress ( $g_{s}$ values from 0.15 to $0.05 \mathrm{~mol} / \mathrm{m}^{2} / \mathrm{sec}$ ) ranged between 41.5 and $110.3 \mu \mathrm{mol} / \mathrm{mol}$ and 0.9 and $4.6 \mathrm{mmol} / \mathrm{mol}$, respectively.

\section{Vine water status and stomatal sensitivity factor}

A significant linear relationship was observed between $\Psi_{\mathrm{s}}$ and $\mathrm{g}_{\mathrm{s}}\left(\mathrm{r}^{2}=0.39\right)$ for measurements taken before and after véraison, with an increasing scattering from -1.6 to $-0.4 \mathrm{MPa}$ (Fig. 5). In addition, a very large scattering of $g_{s}$ was observed for $\Psi_{s}$ ranging between
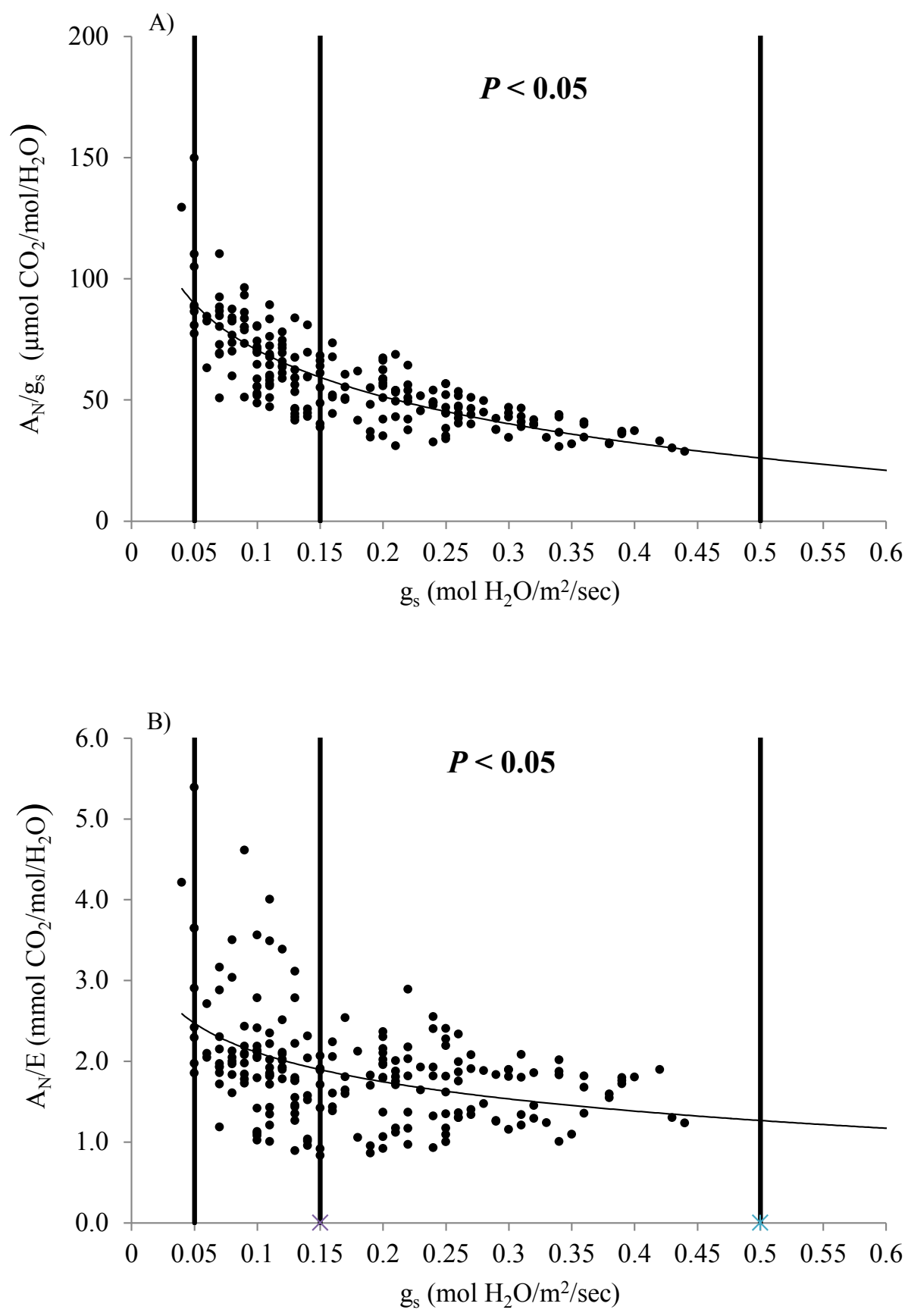

FIGURE 4

Relationships between intrinsic water-use efficiency [ratio of net $\mathrm{CO}_{2}$ assimilation $\left(\mathrm{A}_{\mathrm{N}}\right)$ to stomatal conductance $\left(\mathrm{g}_{\mathrm{s}}\right)$ ] and $\mathrm{g}_{\mathrm{s}}$, and water-use efficiency [ratio of $A_{N}$ to leaf transpiration $(E)$ ] and $g_{s}$ of grapevine (cv. Carménère) growing at field conditions. Solid vertical lines represent the threshold values proposed by Cifre et al. (2005) to define water stress using stomatal conductance as an index: $g_{\mathrm{s}}$ values from 0.5 to $0.15,0.15$ to 0.05 and $<0.05 \mathrm{~mol} \mathrm{H}_{2} \mathrm{O} / \mathrm{m}^{2} / \mathrm{sec}$ correspond to mild, moderate and severe water stress phases, respectively. 
-0.4 and -0.9 $\mathrm{MPa}$. For this range, the cv. Carménère maintained values of stomatal conductance $>0.1 \mathrm{~mol} / \mathrm{m}^{2} / \mathrm{sec}$. Also, Fig. 5 shows that stressed and non-stressed leaves were observed both before (black circles) and after (white circles) véraison. Finally, leaves under severe water stress $\left(\Psi_{\mathrm{s}}<\right.$ $-1.4 \mathrm{MPa}$ ) were only observed in the véraison-pre-harvest period in the 2005/2006 season (Fig. 1).

The stomatal sensitivity $(k)$ calculated for the water deficit ranges suggested by Van Leeuwen et al. (2009) is indicated in Fig. 6. This figure shows that $k$ decreased as water stress increased, with values of 234 and 120 for no and severe water stress respectively. Moreover, Fig. 7 indicates that the values of $k$ ranged between 264 and 480 and 255 and 297 for the measurements taken before and after véraison respectively. In this case, values of $r^{2}$ for the linear regressions between $g_{s}$ and the 'Ball factor' ranged between 0.23 and 0.78 .

\section{DISCUSSION}

\section{Gas exchange behaviour under open field conditions}

The response of plants to drought is generally categorised as being typical for desiccation or drought tolerance mechanisms instead of drought avoidance, since drought is a form of stress that all plants can tolerate but none can avoid. In this regard, we can distinguish between desiccation postponement (the ability to maintain tissue hydration) and desiccation tolerance (the ability to function while dehydrated), which sometimes are referred to as drought tolerance at high and low water potentials respectively. For grapevines, the range of observed responses exhibited by the different cultivars is very large (Chaves et al., 2010) and several classifications seem possible. Based on all the parameters measured in the present study, the cultivar Carménère could be classified as drought tolerant at low water potentials, with a large range of physiological parameters changing in response to water stress. The stomatal aperture reflects the differential turgor between guard cells and neighbouring cells. The epidermal turgor can be affected by humidity and drought, so that appropriate stomatal responses could occur passively (i.e. hydraulically) without any active (i.e. metabolic) involvement (Schultz, 2000). In the case of the cultivar Carménère, the results show that its stomatal closure cannot be purely hydraulic, since the stomata remained partially open even at $\Psi$ s between -1.6 and -1.4 MPa (severe water stress) (Fig. 5). This result suggests that, for complete stomatal closure to occur, an extra signal from the roots may be needed (i.e. ABA). In this regard, Sauter et al. (2001) suggested that the stomatal sensitivity to the root signal could vary in different cultivars.

In this study of field-grown grapevines, a good hyperbolic relationship was observed between $A_{N}$ and $g_{s}$, with a large scattering of the data. The $A_{N}-g_{s}$ relationship was observed for different cultivars under non-irrigated and irrigated conditions (both field- and pot-grown vines), which suggests

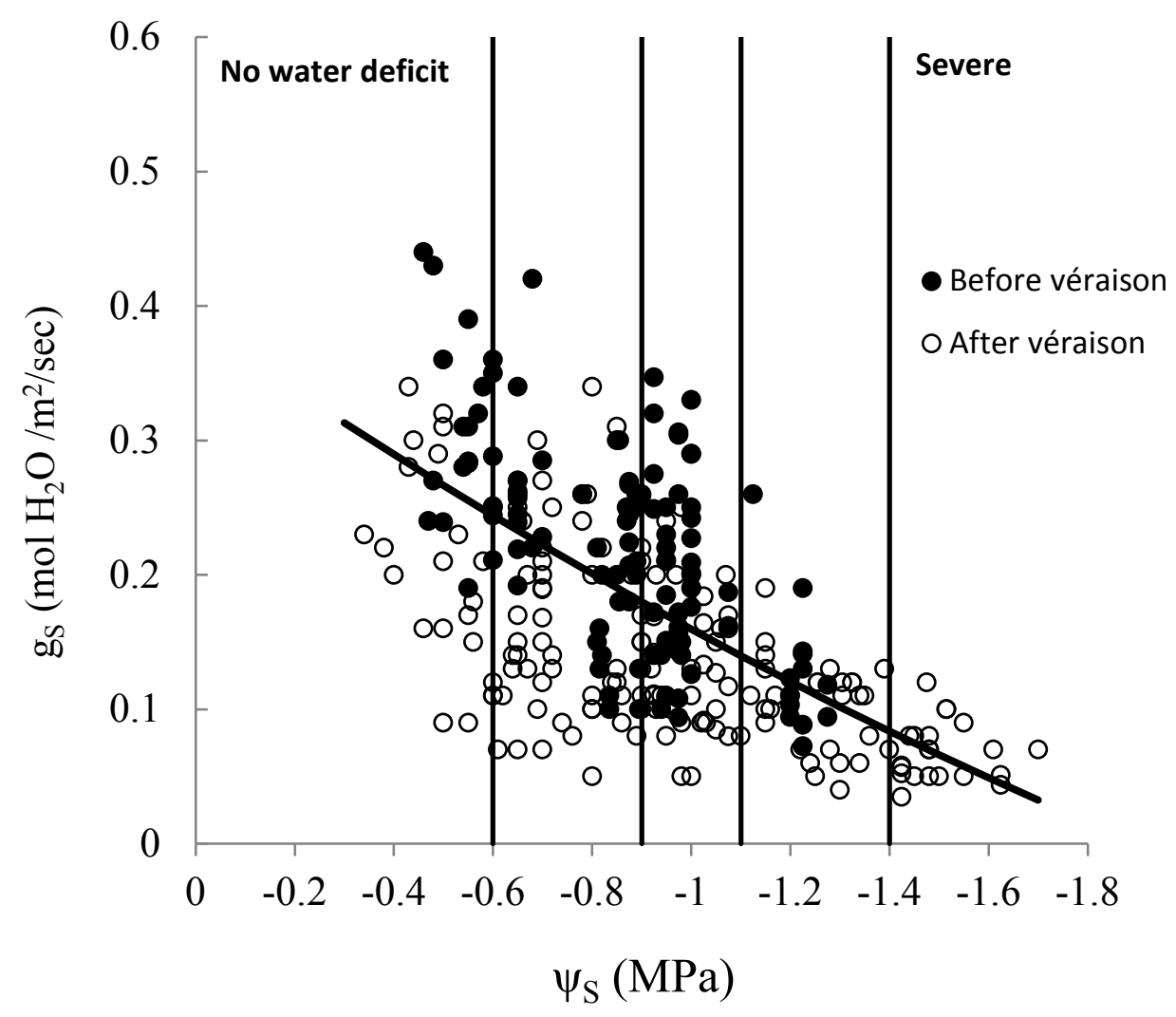

FIGURE 5

Relationship between stomatal conductance $\left(\mathrm{g}_{\mathrm{s}}\right)$ and midday stem water potential $(\Psi \mathrm{s})$ of cv. Carménère under different water stress conditions. The dataset was divided into measurements taken before (black circles) and after véraison (white circles).

Lines represent the thresholds to define water stress levels according to Van Leeuwen et al. (2009). 
that this association can be used as an integrative tool to evaluate the response of different photosynthetic processes to drought (Flexas et al., 2002; Medrano et al., 2002; Cifre et al., 2005). In this regard, it should be mentioned that the maximum value of $A_{N}$ observed in this study was close to $15 \mu \mathrm{mol} / \mathrm{m}^{2} / \mathrm{sec}$, which is lower than that $\left(19 \mu \mathrm{mol} / \mathrm{m}^{2} / \mathrm{sec}\right)$ reported by Medrano et al. (2002). The large scattering of gas exchange measurements reported in this study have also been observed in field-grown and potted grapevines under different growing conditions (Flexas \& Medrano, 2002; Flexas et al., 2002; Medrano et al., 2002). The factors that can explain this scattering are related to the constantly changing light, temperature and vapour pressure conditions present across the canopy (Flexas \& Medrano, 2002; Flexas et al., 2002; Medrano et al., 2002). The values of $\mathrm{A}_{\mathrm{N}}$ and $\mathrm{g}_{\mathrm{s}}$ observed in this study are within the ranges indicated in the literature for isohydric (Mourvèdre, Manto Negro, Tempranillo, Grenache and Ekigaïna) and anisohydric (Syrah and Marselan) cultivars growing under different levels of water stress. For instance, Romero et al. (2010) indicated that $\mathrm{A}_{\mathrm{N}}$ and $\mathrm{g}_{\mathrm{s}}$ ranged between 4 and $16 \mu \mathrm{mol} / \mathrm{m}^{2} / \mathrm{sec}$ and 0.03 and $0.3 \mathrm{~mol} / \mathrm{m}^{2} / \mathrm{sec}$, respectively for $\mathrm{cv}$. Mourvèdre. Flexas and Medrano (2002) observed that $\mathrm{A}_{\mathrm{N}}$ was between 0 and $18 \mu \mathrm{mol} / \mathrm{m}^{2} / \mathrm{sec}$ and $\mathrm{g}_{\mathrm{s}}$ was between 0 and $0.5 \mathrm{~mol} / \mathrm{m}^{2} / \mathrm{sec}$ for Manto Negro and Tempranillo, while Prieto et al. (2010) indicated that $\mathrm{A}_{\mathrm{N}}$ was between 0 and $21 \mu \mathrm{mol} / \mathrm{m}^{2} / \mathrm{sec}$ and that $\mathrm{g}_{\mathrm{s}}$ ranged between 0 and $0.4 \mathrm{~mol} / \mathrm{m}^{2} / \mathrm{sec}$ for the cvs Syrah, Marselan, Grenache, Mourvèdre and Ekigaïna. Finally, Chaves et al. (2007) observed that $\mathrm{A}_{\mathrm{N}}$ and $\mathrm{g}_{\mathrm{s}}$ ranged between 4 and $15 \mu \mathrm{mol} / \mathrm{m}^{2} / \mathrm{sec}$ and 0.05 and $0.3 \mathrm{~mol} / \mathrm{m}^{2} / \mathrm{sec}$ for the cvs Moscatel and Castelão, respectively.
With regard to water-use efficiencies, Cifre et al. (2005) and Flexas et al. (2010) indicated that a decreasing range of $\mathrm{g}_{\mathrm{s}}$, from 0.5 to $0.05 \mathrm{~mol} / \mathrm{m}^{2} / \mathrm{sec}$ produces a decline in $\mathrm{A}_{\mathrm{N}}$, which results in the progressive increase of WUEi. This pattern was also found in the ungrafted Carménère grapevines growing under field conditions. According to Romero et al. (2010) and Prieto et al. (2010), WUEi ranged between 10 and $230 \mu \mathrm{mol} / \mathrm{mol}$ in isohydric and anisohydric cultivars. These values of WUEi are similar to those reported in this study for the $\mathrm{cv}$. Carménère under midday stem water potentials, ranging from -0.3 to $-1.7 \mathrm{MPa}$. From a plant physiological point of view, WUEi should be understood as a cultivar-specific way to express water-use efficiency, since it avoids the large fluctuations observed in the values of WUE $\left(\mathrm{A}_{\mathrm{N}} / \mathrm{E}\right)$ that are caused by differences in evaporative demand without changes in stomatal conductance (Schultz, 2000).

\section{Stomatal conductance response under changing plant water status}

Similar distributions of $\Psi_{\mathrm{s}}$ for the $\mathrm{g}_{\mathrm{s}}$ values ranging from 0.45 to about $0.05 \mathrm{~mol} / \mathrm{m}^{2} / \mathrm{sec}$ were observed regardless of whether the data was collected before or after véraison (Fig. 5). The lowest values of $\Psi_{\mathrm{s}}$ and $\mathrm{g}_{\mathrm{s}}$ observed after véraison can be explained through the water restriction observed in the 2005/2006 season. These results are similar to the ones reported by Prieto et al. (2010) in their work with anisohydric grapevine cultivars (Syrah and Marselan).

The stomatal sensitivity values reported in this study (Figs 6 and 7) are similar to those found by Schultz et al. (1999), who reported that the $k$ values changed over the growing season, going from high (poorly sensitive) in the early season to lower

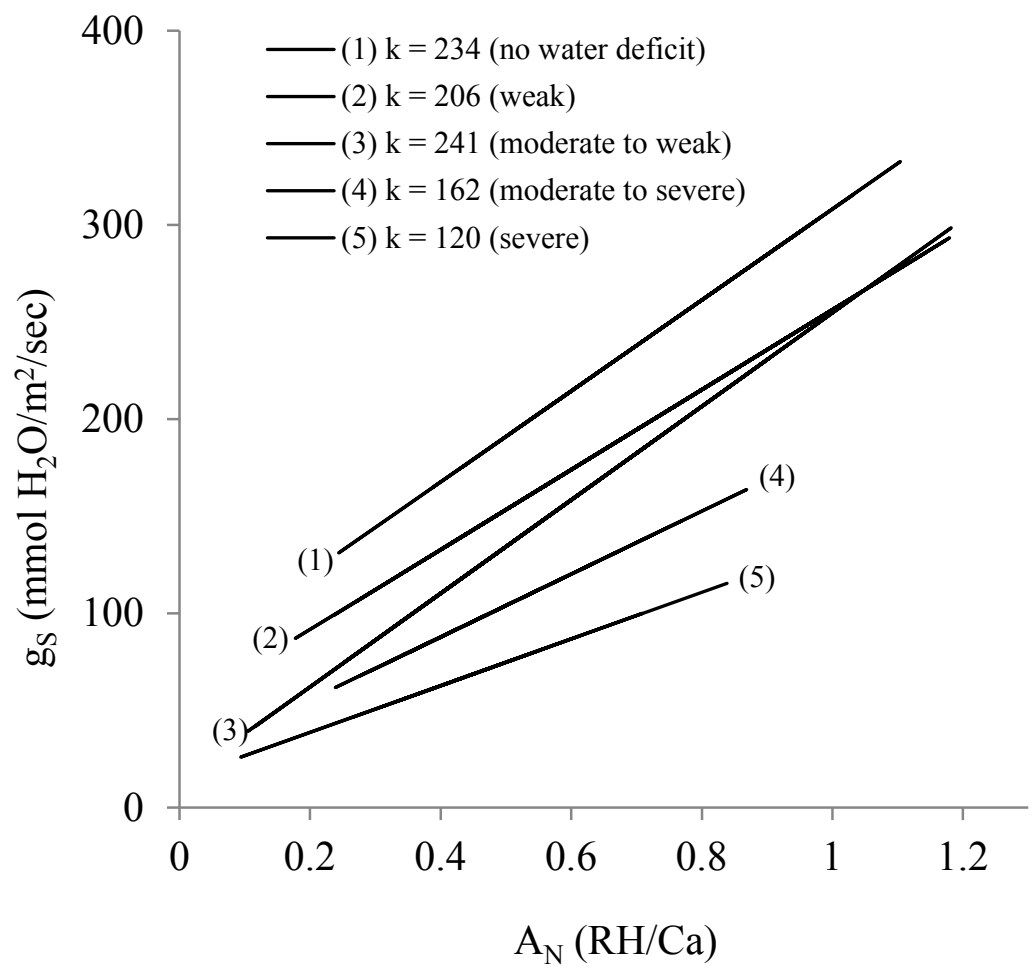

FIGURE 6

Relationship between stomatal conductance $\left(\mathrm{g}_{\mathrm{s}}\right)$ and the 'Ball factor' $\left[\mathrm{A}_{\mathrm{N}}(\mathrm{RH} / \mathrm{Ca})\right]$ of cv. Carménère under different water stress conditions. Lines represent thresholds to define water stress levels according to Van Leeuwen et al. (2009). 
values as véraison and harvest approached. In addition, these authors indicated that high values of $k$ (inverse relationship with stomatal closure control) are associated with cultivars with low stomatal sensitivity to stressful environmental conditions. Furthermore, these authors also indicated that $k$ ranged between 73 and 159 in anisohydric cultivars (Riesling, Chardonnay, Cabernet Sauvignon, Syrah, Touriga Nacional and Semillon) and had a value of 83 in an isohydric cultivar (Grenache). Prieto et al. (2010) observed $k$ values of 150 and 120 in anisohydric (cv. Syrah) and isohydric (cv. Ekigaïna) grapevines respectively. The decrease in $k$ may reflect the effect of shoot lignification late in the season, which alters the hydraulic capabilities of plant organs such as shoots and leaves. In the present study, véraison and shoot lignification usually started in the second half of January, a period that coincides with the shift in stomatal sensitivity (Schultz et al., 1999; Schultz, 2000). Fig. 7 indicates that the values of $k$ were higher before than after veraison for the Carménère grapevines. In this regard, Speirs et al. (2013) indicated that the stomatal sensitivity increased (lower values) as the level of water stress increased, possibly due to an earlier or accelerated shoot lignification induced as a response of stress-hormone feedback. Similarly, Schultz (2000) observed that the stomatal sensitivity increased as the pre-dawn water potential decreased.

In Carménère, the transpiration could be sustained, despite presenting a large leaf area (GDC training system supports large canopies) through less sensitive stomata. In this case, the system needs a high water transport capacity in the soil-plant-atmosphere continuum and might be less sensitive to xylem embolisms. In this regard, Zufferey et al. (2011) described diurnal cycles of embolism formation and repair in petioles of stressed grapevines (cv. Chasselas). Nevertheless, the results showed that once véraison was reached, the stomatal sensitivity factor shifted to a more responsive state (Fig. 7), possibly because of the natural lignification of shoots, which resulted in a more conservative water behaviour after this period (Domec \& Johnson, 2012; Rogiers et al., 2012; Zhang et al., 2012).

\section{CONCLUSIONS}

In this study, significant non-linear relationships were observed between $\mathrm{A}_{\mathrm{N}}$ and $\mathrm{g}_{\mathrm{s}}\left(\mathrm{r}^{2}=0.82\right) \mathrm{Ci}$ and $\mathrm{g}_{\mathrm{s}}\left(\mathrm{r}^{2}=0.54\right)$ and $\mathrm{A}_{\mathrm{N}} / \mathrm{Ci}$ and $\mathrm{g}_{\mathrm{s}}\left(\mathrm{r}^{2}=0.49\right)$ for ungrafted Carménère grapevines
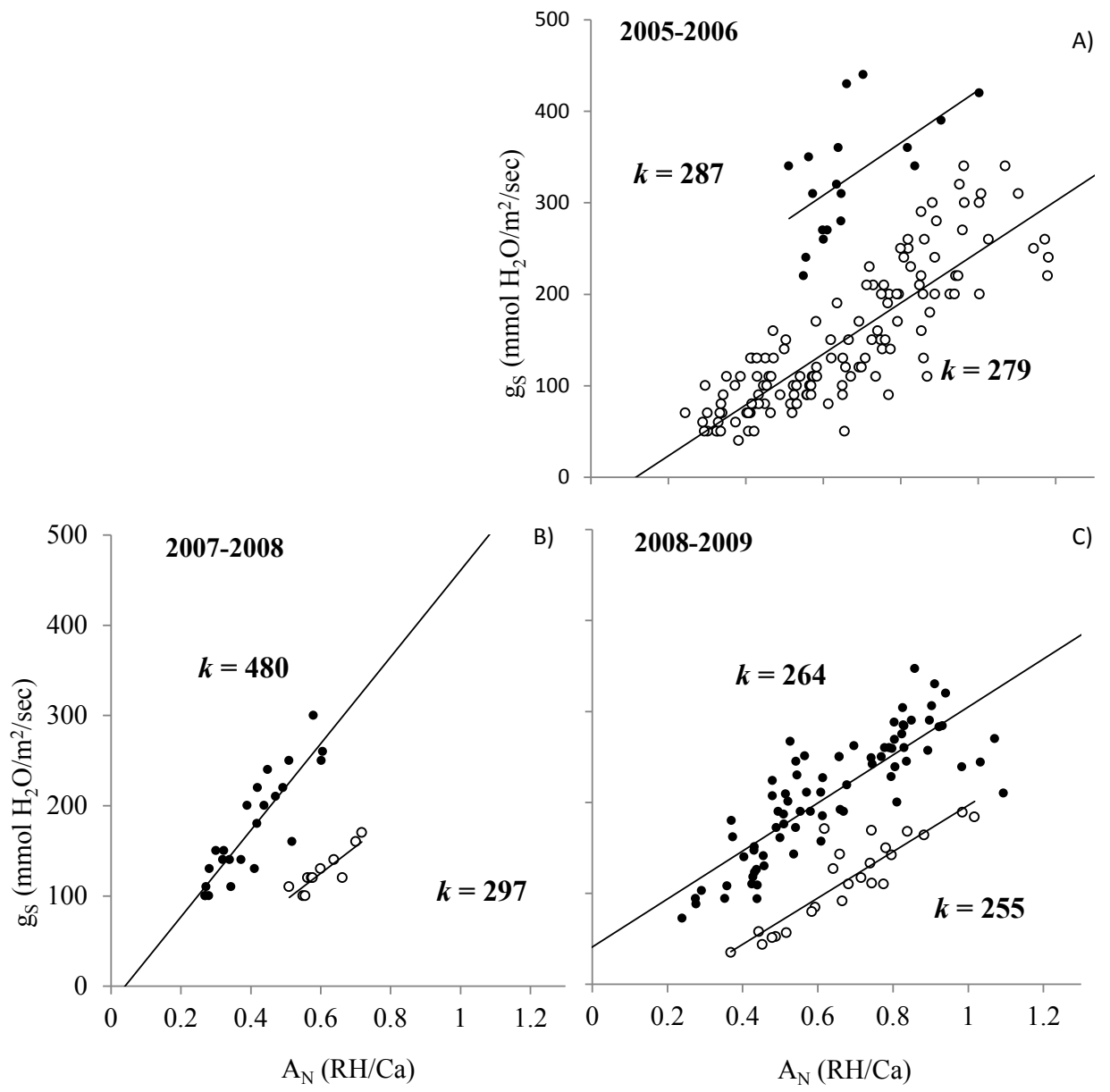

FIGURE 7

Stomatal sensitivity factor $(k)$ of field-grown grapevines (cv. Carménère). The linear regressions between $\mathrm{g}_{\mathrm{s}}$ and the 'Ball factor' were: A) 2005/2006: $\mathrm{y}=287.49(\mathrm{x})+135.78\left(\mathrm{r}^{2}=0.35\right)$ and $\mathrm{y}=278.61(\mathrm{x})-32.076\left(\mathrm{r}^{2}=0.72\right)$ for black and white circles respectively; B) 2007/2008: $\mathrm{y}=480.05(\mathrm{x})-18.951\left(\mathrm{r}^{2}=0.78\right)$ and $\mathrm{y}=105.44(\mathrm{x})+58.706\left(\mathrm{r}^{2}=0.23\right)$ for black and white circles respectively; C) 2008/2009: $\mathrm{y}=263.89(\mathrm{x})+41.05\left(\mathrm{r}^{2}=0.70\right)$ and $\mathrm{y}=254.85(\mathrm{x})-57.907\left(\mathrm{r}^{2}=0.79\right)$ for black and white circles respectively. The black and white circles indicate measurements taking before and after véraison, respectively. 
growing in a drip-irrigated commercial vineyard. The values of $\mathrm{A}_{\mathrm{N}}$ diminished from 14.9 to $3.5 \mu \mathrm{mol} / \mathrm{m}^{2} / \mathrm{sec}$ as $\mathrm{g}_{\mathrm{s}}$ decreased from 0.5 to $0.05 \mathrm{~mol} / \mathrm{m}^{2} / \mathrm{sec}$, which resulted in a progressive increase in WUEi. In this cases, the mean values of WUEi for mild water stress ( $g_{s}$ values from 0.5 to $0.15 \mathrm{~mol} / \mathrm{m}^{2} / \mathrm{sec}$ ) ranged between 28.7 and $73.4 \mu \mathrm{mol} / \mathrm{mol}$, while those for moderate water stress $\left(\mathrm{g}_{\mathrm{s}}\right.$ values from 0.15 to $0.05 \mathrm{~mol} / \mathrm{m}^{2} / \mathrm{sec}$ ) ranged between 41.5 and $110.3 \mu \mathrm{mol} / \mathrm{mol}$. Also, a significant linear relationship was observed between $\Psi \mathrm{s}$ and $\mathrm{g}_{\mathrm{s}}\left(\mathrm{r}^{2}=0.39\right)$ for measurements taken before and after véraison, with an increasing scattering from -1.6 to $-0.4 \mathrm{MPa}$. Finally, $k$ decreased as water stress increased, with values of 234 and 120 for no and severe water stress respectively, while $k$ ranged between 264 and 480 and 255 and 297 for the measurements taken before and after véraison respectively. Based on all the parameters measured in the present study, the cultivar Carménère could be classified as drought tolerant at low water potentials, with a large range of physiological parameters changing in response to water stress.

\section{LITERATURE CITED}

Allen, R.G., Pereira, L.S., Raes, D. \& Smith, M., 1998. Crop evapotranspiration: Guidelines for computing crop water requirements. FAO Irrigation and Drainage Paper number 56.

Acevedo-Opazo, C., Ortega-Farias, S. \& Fuentes, S., 2010. Effects of grapevine (Vitis vinifera L.) water status on water consumption, vegetative growth and grape quality: An irrigation scheduling application to achieve regulated deficit irrigation. Agric. Water Manage. 97, 956-964.

Ball, J.T., Woodrow, I.E. \& Berry, J.A., 1987. A model predicting stomatal conductance and its contribution to the control of photosynthesis under different environmental conditions. Prog. Photosynthesis Res. Proc. $7^{\text {th }}$ Int. Congress, August 1986, Providence, USA, Vol. 4. pp. 221-224.

Basile, B., Girona, J., Behboudian, M.H., Mata, M., Rosello, J., Ferré, M. \& Marsal, J., 2012. Responses of "Chardonnay" to deficit irrigation applied at different phenological stages: Vine growth, must composition, and wine quality. Irrigation Sci. 30(5), 397-406. doi:10.1007/s00271-012-0353-1

Begg, J.E. \& Turner, N.C., 1970. Water potential gradients in field tobacco. Plant Physiol. 46(2), 343-346.

Candolfi-Vasconcelos, M.C. \& Koblet, W., 1991. Influence of partial defoliation on gas exchange parameters and chlorophyll content of fieldgrown grapevines: Mechanisms and limitations of the compensation capacity. Vitis 30(3), 129-141.

Carbonneau, A. \& Costanza, P., 2004. Response of vine leaf water potential to quick variation in canopy exposure. Example of canopy opening manipulation of merlot (Vitis vinifera L.). J. Int. Sci. Vigne Vin 38(1), 27-33.

Chaves, M.M., Santos, T.P., Souza, C.R., Ortuño, M.F., Rodrigues, M.L., Lopes, C.M., et al., 2007. Deficit irrigation in grapevine improves water-use efficiency while controlling vigour and production quality. An. Appl. Biol. 150(2), 237-252. doi:10.1111/j.1744-7348.2006.00123.x

Chaves, M.M., Zarrouk, O., Francisco, R., Costa, J.M., Santos, T., Regalado, A.P., Rodrigues, M.L., et al., 2010. Grapevine under deficit irrigation: Hints from physiological and molecular data. Ann. Bot. 105(5), 661-676. doi:10.1093/aob/mcq030

Choné, X., Van Leeuwen, C., Dubourdieu, D. \& Gaudillere, J., 2001. Stem water potential is a sensitive indicator of grapevine water status. Ann. Bot. 87(4), 477-483.
Cifre, J., Bota, J., Escalona, J., Medrano, H. \& Flexas, J., 2005. Physiological tools for irrigation scheduling in grapevine (Vitis vinifera L.). An open gate to improve water-use efficiency? Agric. Ecosyst. Environ. 106(2-3), 159170. doi:10.1016/j.agee.2004.10.005

Coombe, B., 1995. Adoption of a system for identifying grapevine growth stages. Aust. J. Grape Wine Res. 1, 104-110.

Domec, J.C. \& Johnson, D.M., 2012. Does homeostasis or disturbance of homeostasis in minimum leaf water potential explain the isohydric versus anisohydric behavior of Vitis vinifera L. cultivars? Tree Physiol. 32(3), 245248. doi:10.1093/treephys/tps013

Fernandes de Oliveira, A., Mameli, M.G., De Pau, L., Satta, D. \& Nieddu, G., 2013. Deficit irrigation strategies in Vitis vinifera L. cv. Cannonau under Mediterranean climate. Part I - Physiological responses, growth, yield and berry composition. S. Afr. J. Enol. Vitic. 34(2), 170-183.

Flexas, J. \& Medrano, H., 2002. Drought-inhibition of photosynthesis in C-3 plants: Stomatal and non-stomatal limitations revisited. Ann. Bot. 89(2), 183-189. doi:10.1093/aob/mcf027

Flexas, J., Bota, J., Escalona, J., Sampol, B. \& Medrano, H., 2002. Effects of drought on photosynthesis in grapevines under field conditions: An evaluation of stomatal and mesophyll limitations. Func. Plant Biol. 29(4), 461-471. doi:10.1071/PP01119

Flexas, J., Galmes, J., Galle, A., Gulias, J., Pou, A., Ribas-Carbo, M., Tomas, M., et al., 2010. Improving water use efficiency in grapevines: Potential physiological targets for biotechnological improvement. Aust. J. Grape Wine Res. 16, 106-121. doi:10.1111/j.1755-0238.2009.00057.x

Jacobs, C.M.J., Van den Hurk, B.M.M. \& De Bruin, H.A.R., 1996. Stomatal behaviour and photosynthetic rate of unstressed grapevines in semi-arid conditions. Agr. Forest Meteorol. 80(2-4), 111-134. doi:10.1016/01681923(95)02295-3

Jara-Rojas, F., Ortega-Farías, S., Valdés-Gómez, H. \& Del Pozo, A., 2009. Model validation for estimating the leaf stomatal conductance in Cabernet Sauvignon grapevines. Chil. J. Agr. Res. 69(1), 88-96.

Medrano, H., Escalona, J., Bota, J., Gulias, J. \& Flexas, J., 2002. Regulation of photosynthesis of $\mathrm{C}-3$ plants in response to progressive drought: Stomatal conductance as a reference parameter. Ann. Bot. 89(7), 895-905. doi:10.1093/aob/mcf079

Moutinho-Pereira, J.M., Correia, C.M., Gonçalves, B.M., Bacelar, E.A. \& Torres-Pereira, J.M., 2004. Leaf gas exchange and water relations of grapevines grown in three different conditions. Photosynthetica 42(1), 8186. doi:10.1023/B:PHOT.0000040573.09614.1d

Naor, A. \& Wample, R., 1995. A rapid field method for measuring net assimilation rate stomatal conductance relationship - a feasibility test using grapevine leaves. Sci. Hortic. 60(3-4), 287-292.

Ortega-Farias, S., Righetti, T., Acevedo, C., Matus, F. \& Moreno, Y., 2005. Irrigation-management decision system (IMDS) for vineyards (Region VI and VII of Chile). Integrated Soil and Water Management for Orchard Development. Land and Water Bulletin number 10, FAO, Rome, Italy.

Pellegrino, A., Goze, E., Lebon, E. \& Wery, J., 2006. A model-based diagnosis tool to evaluate the water stress experienced by grapevine in field sites. European Journal of Agronomy 25(1), 49-59. doi:10.1016/j. eja.2006.03.003

Prieto, J.A., Lebon, E. \& Ojeda, H., 2010. Stomatal behavior of different grapevine cultivars in response to soil water status and air water vapour pressure deficit. J. Int. Sci. Vigne Vin 44(1), 9-20.

Rogiers, S.Y., Greer, D.H., Hatfield, J.M., Hutton, R.J., Clarke, S.J., Hutchinson, P.A. \& Somers, A., 2012. Stomatal response of an anisohydric grapevine cultivar to evaporative demand, available soil moisture and abscisic acid. Tree Physiol. 32(3), 249-261. doi:10.1093/treephys/tpr131 
Romero, P., Fernandez-Fernandez, J. \& Martinez-Cutillas, A., 2010. Physiological thresholds for efficient regulated deficit-irrigation management in winegrapes grown under semiarid conditions. Am. J. Enol. Vitic. 61(3), 300-312.

Sauter, A., Davies, W.J. \& Hartung, W., 2001. The long-distance abscisic acid signal in the droughted plant: The fate of the hormone on its way from root to shoot. J. Exp. Bot. 52(363), 1991-1997.

Scholander, P.F., Bradstreet, E.D., Hemmingsen, E.A. \& Hammel, H.T., 1965. Sap pressure in vascular plants: Negative hydrostatic pressure can be measured in plants. Science 148(3668), 339-346. doi:10.1126/ science.148.3668.339

Schultz, H., 2003. Differences in hydraulic architecture account for nearisohydric and anisohydric behaviour of two field-grown Vitis vinifera L. cultivars during drought. Plant Cell Environ. 26(8), 1393-1405.

Schultz, H.R., 2000. Physiological mechanisms of water use efficiency in grapevines under drought conditions. Acta Hort. 526, 115-136.

Schultz, H.R., Lebon, E. \& Rousseau, C., 1999. Suitability of the "Ball, Woodrow, Berry" model for the description of stomatal coupling to photosynthesis of different Vitis species and Vitis vinifera cultivars in different climatic regions at various levels of water deficit. Acta Hort. (ISHS) 493, 17-30.

Shellie, K.C., 2014. Water productivity, yield, and berry composition in sustained versus regulated deficit irrigation of Merlot grapevines. Am. J. Enol. Vitic. 65(2), 197-205. doi:10.5344/ajev.2014.13112
Sibille, I., Ojeda, H., Prieto, J., Maldonado, S., Lacapere, J. \& Carbonneau, A., 2007. Relation between the values of three pressure chamber modalities (midday leaf, midday stem and predawn water potential) of 4 grapevine cultivars in drought situation of the southern France. Applications for irrigation control. Paper presented at the XVth International Symposium GESCO, June 2007, Porec, Croatia.

Speirs, J., Binney, A., Collins, M., Edwards, E. \& Loveys, B., 2013. Expression of ABA synthesis and metabolism genes under different irrigation strategies and atmospheric VPDs is associated with stomatal conductance in grapevine (Vitis vinifera L. cv Cabernet Sauvignon). J. Exp. Bot. 64(7), 1907-1916. doi:10.1093/jxb/ert052

Tardieu, F. \& Simonneau, T., 1998. Variability among species of stomatal control under fluctuating soil water status and evaporative demand: Modelling isohydric and anisohydric behaviours. J. Exp. Bot. 49, 419-432.

Tonietto, J. \& Carbonneau, A., 2004. A multicriteria climatic classification system for grape-growing regions worldwide. Agr. Forest Meteorol. 124(12), 81-97. doi:10.1016/j.agrformet.2003.06.001

Van Leeuwen, C., Trégoat, O., Choné, X., Gaudillère, J.-P. \& Pernet, D., 2009. Different environmental conditions, different results: The role of controlled environmental stress on grape quality potential and the way to monitor it. Proc. $13^{\text {th }}$ Aust. Wine Industry Techn. Conf., July/August 2009, Adelaide, Australia. pp. 1-8.

Zhang, Y., Oren, R. \& Kang, S., 2012. Spatiotemporal variation of crownscale stomatal conductance in an arid Vitis vinifera L. cv. Merlot vineyard: Direct effects of hydraulic properties and indirect effects of canopy leaf area. Tree Physiol. 32(3), 262-279. doi:10.1093/treephys/tpr120

Zufferey, V., Cochard, H., Ameglio, T., Spring, J.-L. \& Viret, O., 2011. Diurnal cycles of embolism formation and repair in petioles of grapevine (Vitis vinifera cv. Chasselas). J. Exp. Bot. 62(11), 3885-3894. doi:10.1093/ $\mathrm{jxb} / \mathrm{err} 081$ 